
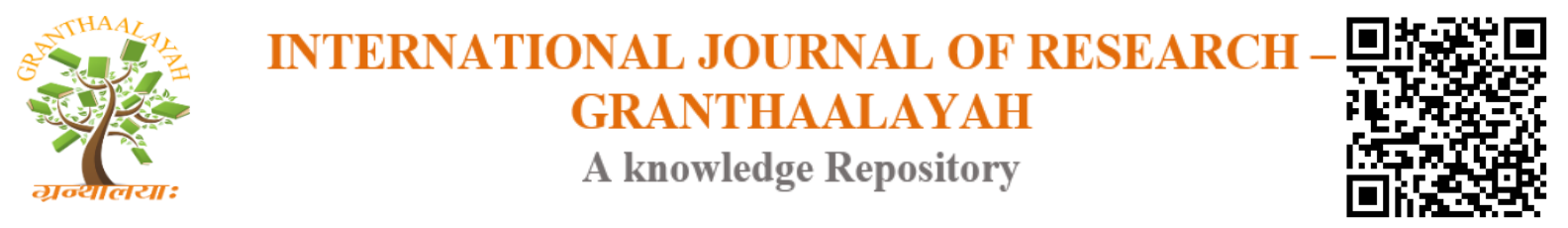

Science

\title{
SOCIO-ECONOMIC UPLIFTING ANALYSIS OF ESBN FISHERY OF THE COASTAL VILLAGES, KUMIRA AND KATTOLI, CHITTAGONG, BANGLADESH
}

\author{
Md. Atiqul Islam Mondal *1, M. A. Kader ${ }^{1}$, Anwar Hossain Choudhury ${ }^{2}$, Muhammad \\ Golam Mustafa ${ }^{3}$, Md. Rashed-Un-Nabi ${ }^{1}$, Md Masum Billah ${ }^{4}$, Abdulla-Al-Asif 5,6, \\ Abdullah Al Mamun Siddiqui ${ }^{1}$ \\ ${ }^{1}$ Institute of Marine Sciences and Fisheries, University of Chittagong, Chittagong-4331, \\ Bangladesh \\ ${ }^{2}$ Department of Sociology, University of Chittagong, Chittagong-4331, Bangladesh \\ ${ }^{3}$ Department of Oceanography, Noakhali Science and Technology University, Noakhali-3814, \\ Bangladesh \\ ${ }^{4}$ Department of Land Management, Faculty of Agriculture, Universiti Putra Malaysia, 43400 \\ UPM, Serdang, Selangor Darul Ehsan \\ ${ }^{5}$ Department of Aquaculture, Faculty of Fisheries, Bangladesh Agricultural University,
} Mymensingh, 2202, Bangladesh

${ }^{6}$ Department of Fisheries and Marine Bioscience, Faculty of Biological Science and Technology, Jashore University of Science and Technology, Jashore, Bangladesh.

\begin{abstract}
The study was conducted in 2 ESBN fishing villages namely Kumira and another is South Kattoli coordinates namely, $22^{\circ} 30^{\prime} 58.9^{\prime \prime} \mathrm{N}$ and $91^{\circ} 41^{\prime} 37.1^{\prime \prime} \mathrm{E}$ for Kumira and $22^{\circ} 21^{\prime} 06.6^{\prime \prime} \mathrm{N}$ and $91^{\circ} 45^{\prime} 27.8$ "E for South Kattoli during January to December, 2005 and further study is conducted in January to June, 2018. It was found, in 2005 Kattoli and Kumira has largest portion of the 2030 age group, $55 \%$ and 58\% respectively and according to survey, in 2018 it was found 30-40 age group is dominant as $50 \%$ and $46 \%$ of total fisher population. The total family number of the study area is 580 in Kattoli and 550 in Kattoli in 2005 whereas; total family number of the study area is increasing in 2018. There are about 65\% Hindu communities and 35\% Muslim in Kattoli where Kumira comprises $80 \%$ Hindu (jolodash) and 20\% Muslim in 2005 where muslim population is incresasing in 2018. There are significant number of secondary education holder population is increasing in 2018 comparison to 2005. According to study, the total population of Kattoli were 867 , out of which about $52 \%$ male and $48 \%$ female in 2005 and about $57 \%$ male and $43 \%$ female in 2018. In Kumira village, total population was 670, out of which about $60 \%$ male and $40 \%$ female in 2005 and about $55 \%$ male and $45 \%$ female in 2018. Concrete made building is increasing in 2018 in the study area. Shallow and deep tube well number is also increasing in study area. Use of utility electricity, television, cassette player/radio, VCR/CD player and mobile phone are also increasing in study area. Rich and moderate rich number is increasing in comparison with 2005. Visit to the MBBS doctor trend instead of quack doctor is increasing in study area. Daily
\end{abstract}


meal uptake by thee meal has a increasing trend in the study area. Overall the wealth is increasing in the study area.

Keywords: Socio-Economic Status; Uplifting; Estuary Set-Bag Net; Coastal Villages; Chittagong.

Cite This Article: Md. Atiqul Islam Mondal, M. A. Kader, Anwar Hossain Choudhury, Muhammad Golam Mustafa, Md. Rashed-Un-Nabi, Md Masum Billah, Abdulla-Al-Asif, and Abdullah Al Mamun Siddiqui. (2018). "SOCIO-ECONOMIC UPLIFTING ANALYSIS OF ESBN FISHERY OF THE COASTAL VILLAGES, KUMIRA AND KATTOLI, CHITTAGONG, BANGLADESH." International Journal of Research - Granthaalayah, 6(8), 248-263. https://doi.org/10.29121/granthaalayah.v6.i8.2018.1458.

\section{Introduction}

Bangladesh is endowed with vast inland and marine water resources where large numbers of fishermen are engaged in fishing. Fisheries sector provides full time employment to an estimated 20 million people comprising of full-time fishermen, small fish traders, fish transporters, processors, packers etc, (World Bank 1998). Beside this, about 10 millions people are directly or indirectly involved in fishing and /or related occupation (Islam, 1994). Fishery resources play a very important role in economy of Bangladesh and about $80 \%$ of the animal proteins contributed by the fisheries item. About $10.7 \%$ million people are directly on indirectly related with different fishery activity (Khan, 1982). The marine fisheries comprise with two subsectors-artisanal fisheries and industrial fisheries. Small-scale artisanal fishing is carried out mostly by traditional mechanized boats and industrial fishing is done by trawler. The number of motorized boats used for small-scale marine fishing are same for the period 1985-86 to 1988-89 but from other sources (World Bank, 1998; Chong et al., 1991, Islam and Elahi, 1993) indicate that the actual number of boat is more than 5000 and most of them are unregistered. It appears that 1.3 million fishermen were engaged in fishing, of which $60 \%$ and $40 \%$ in inland and marine fisheries respectively. In inland capture fisheries, number of fishermen increased by $6 \%$ from 1979-80 to 1988-89 but in the same period, the marine fishermen increased by $50 \%$ which indicates that more fishermen are getting engaged in small-scale marine fishing (Islam, 1994). In Bangladesh, marine fisheries are dominated by small-scale marine fisheries. It contributes about $96 \%$ of the total marine catch and provides employment to 497000 fulltime and 2525000 part-time fishermen (Chong et al., 1991). Fishers live in unhygienic condition without proper drinking water and sanitation facility, about $32 \%$ of the households are solely dependent on ESBN, $62 \%$ combined other fishery or non-fishing activities, and $11 \%$ labor household in the village surveyed. This is a family-oriented enterprise; they do not know anything else but to go to set their net respective of availability to catch or not. In Cox's Bazar area the catch is comparatively high, as much as seven times and $92 \%$ fishermen of this area live above the poverty level, having an average income of taka 100000 per annum (Khan, 1994). The estuarine set bag-net fishery (ESBN) of Bangladesh is one of the country's most important traditional fisheries, a large population of small-scale fisher-folk having been dependent on it for a long time. Because of the interactive nature of many of the marine fisheries, it was necessary, for the assessment and management of any one fishery, to consider the other fisheries exploiting the same resources. The ESBN fishery engages about 55,000 fishermen, and around 851000000 fisher folk are dependent on it for their livelihood. The majorities of these fisher-folk, particularly the women, are illiterate, live under temporary roofs because of the destructive effects 
of frequent cyclones and have poor amenities except for, perhaps, primary schools (Khan et al., 1994). A study has shown that ESBN owing households are 82 percent of the total number of households in the study area, but only 25 percent of ESBN owners have other fishing gears (Mustafa, 1994). Set bag nets have been used in the rivers (freshwater), estuaries and coastal marine waters of Bangladesh. The estuarine set bag nets contribute about 20 percent of the total fish landings of the country. But many studies have shown that set bag nets land a lot of juveniles, especially shrimp, and if this practice goes unregulated there is bound to occur serious biological degradation of fishery resources (Thomson et al., 1993). An empirical study was sponsored in 1989-90 by the Bay of Bengal Programme (BOBP) to provide, using an interdisciplinary framework of analysis, a better understanding of the complex sets of interrelationships in the biological and socioeconomic spheres of the Bangladesh estuarine set bag net fisheries and the people involved (Bay of Bengal News, Issue No.47.1992, Khan (1993) for details. The present study was conducted to analyze the socio-economic uplifting of the fishermen to reveal the livelihood strategy of the fishermen.

\section{Materials and Methods}

\section{Study Area and Periods}

The study was conducted in 2 ESBN fishing villages namely Kumira and another is South Kattoli

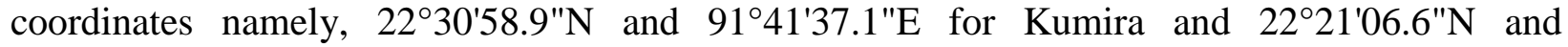
$91^{\circ} 45^{\prime} 27.8$ "E for South Kattoli during January to December, 2005 and further study is conducted in January to June, 2018.

\section{Data Collection}

A number of methods were used for collecting data for this study. The main data collection technique of the study was a survey having semi-structured question discussion with local people in specific points. The other techniques used for using participatory tools PRA (Participatory Rural Appraisal) as, Focus Group Discussion (FGD); transect work and seasonal calendar; daily activity; mobility chart; social mapping; key informant interview and photo plate etc.

\section{Sampling of FGD Respondents}

The sampling technique was purposive because it was necessary to select those persons who would be able to provide most useful information on the question. Each group consists of $6-8$ persons.

\section{Transect Walk}

The transect walk was done in the village across the main road of the village to know the crop type, soil type, land use, trees, birds and animals.

\section{Wealth Ranking}

The wealth ranking was done with the help of social map and by card. On the social map an every household were identified with serial number.

\section{Seasonal Calendar}

A seasonal calendar was prepared for knowing the method of different socioeconomic activities. Participants of these exercises were fishermen and elderly knowledgeable person from different occupations. This exercise helps to know about the lean season and peak season. 
Daily Activities

DOI: $10.5281 /$ zenodo.1433824

Daily activity chart is needed for knowing the types of activity done in peak season. Participants of this exercise were fishermen and women.

\section{Mobility Chart}

Mobility chart was prepared for knowing the areas where the people goes for their needs and also where they go frequently and their connection with the urban areas. Participants of this exercise were from different occupations.

\section{Key Informant Interview and Case Study}

Key informant interview was done to know important information in education, family planning and other important information. Also about business and its present and past history. Selected key information were, fisherman, bankers, businessman, teacher, elected representatives, house wife etc.

\section{Data Processing and Analysis}

Entire collected data were précised and inspected cautiously and documented. Afterward assortment of data, these were revised and notched. In conclusion, significant tables were prepared in accordance with the objectives of the study. Data presented mostly in the tabular form because it is simple in calculation, widely used and easy to understand. Data were analyzed using the Microsoft excel 2007.

\section{Results}

\section{Age Group}

It was found, in 2005 Kattoli and Kumira has largest portion of the 20-30 age group, 55\% and 58\% respectively and according to survey, in 2018 it was found 30-40 age group is dominant as 50\% and $46 \%$ of total fisher population. There were a limited number of 60 and above age group in both villages (Figure 1).

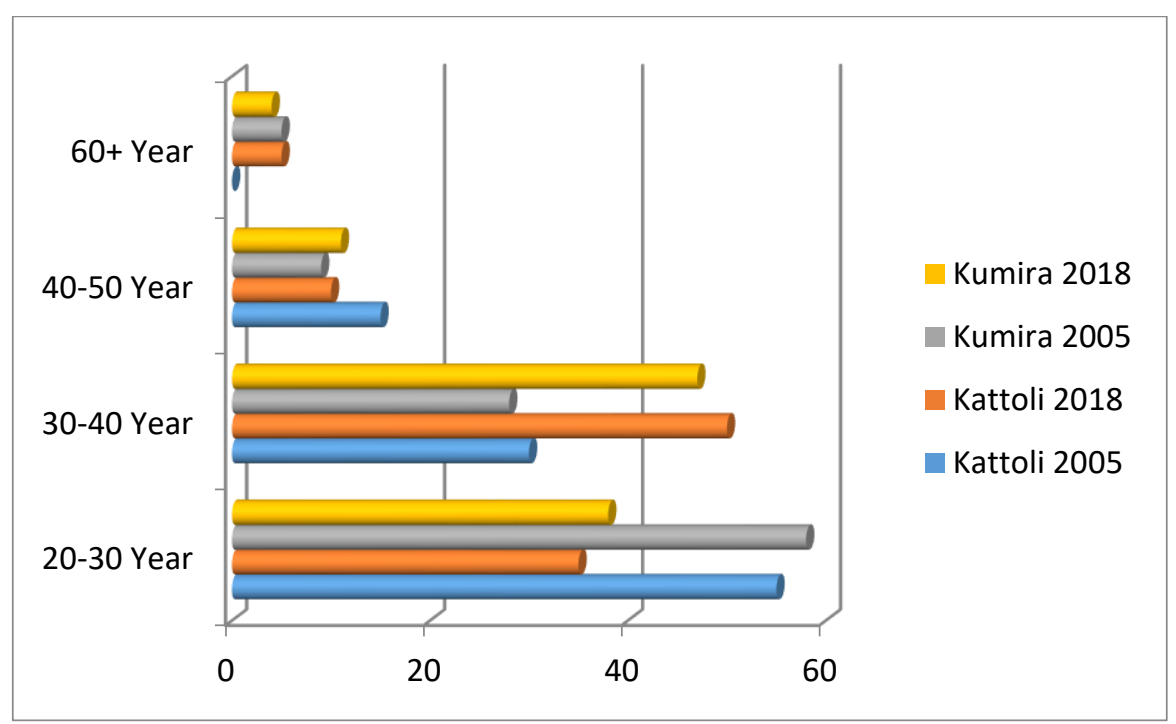

Figure 1: Age structure of the fisher in Kattoli and Kumira villages 


\section{Family Number Studied}

The total family number of the study area is 580 in Kattoli and 550 in Kattoli in 2005 whereas, total family number of the study area is 637 in Kattoli and 623 in Kattoli in 2018 (Figure 2).

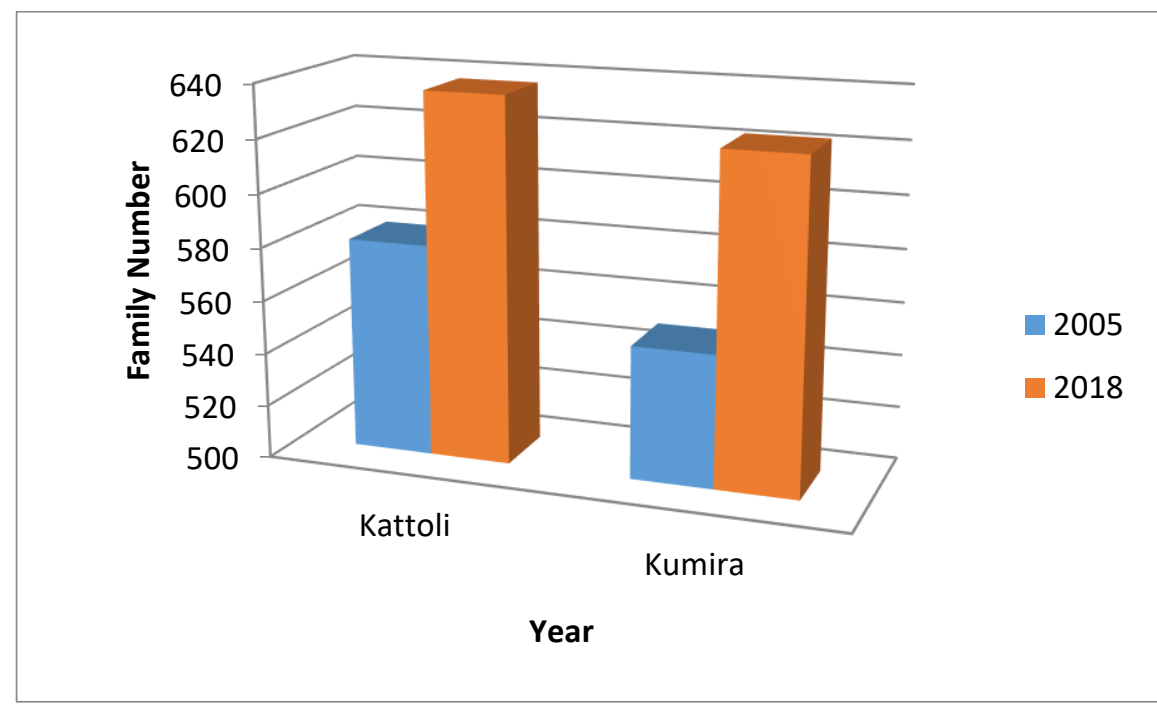

Figure 2: Family number in Kattoli and Kumira villages

\section{Religion}

There are about 65\% Hindu communities and 35\% Muslim in Kattoli where Kumira comprises 80 $\%$ Hindu (jolodash) and 20\% Muslim in 2005 along with there are about 45\% Hindu communities and 55\% Muslim in Kattoli where Kumira comprises $40 \%$ Hindu (jolodash) and 60\% Muslim in 2018 (Figure 3).

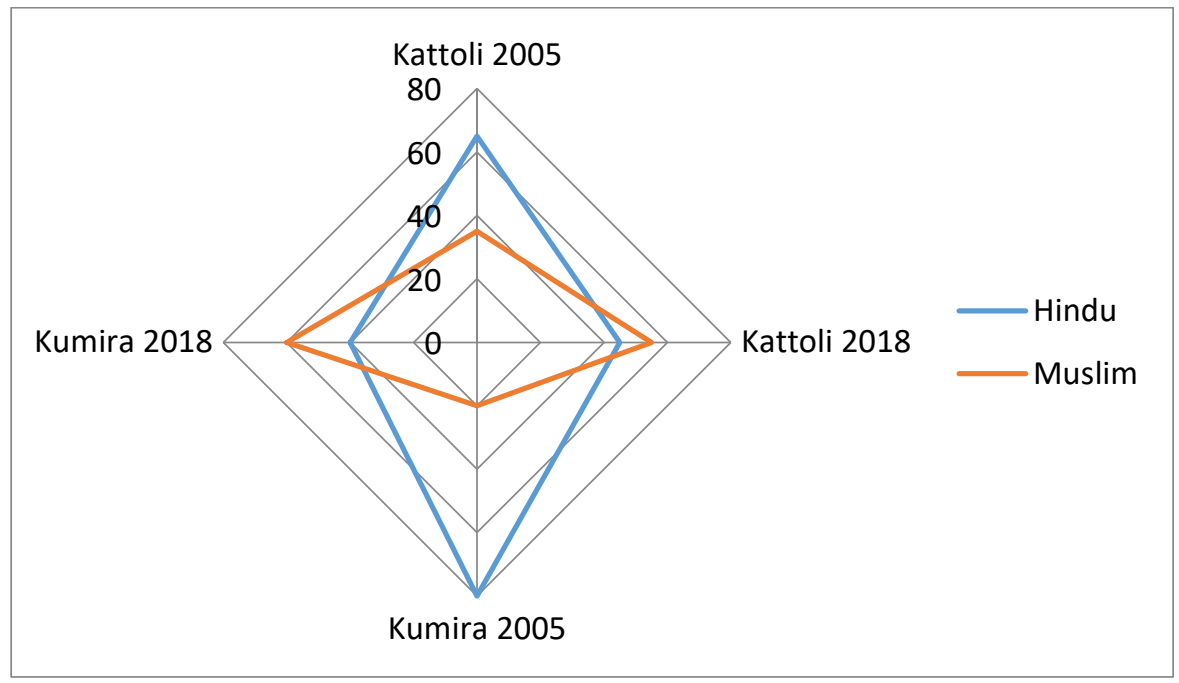

Figure 3: Religion status of fisher in Kattoli and Kumira villages

\section{Education}

The number of primary education obtainer in Kattoli and Kumira in 2005 were significant and the percent were $65 \%$ and $69 \%$ respectively where other education group were negligible to mention. In comprises, 2018 has a dynamic changes over education where, the largest education group were, 
Secondary education obtainer as $45 \%$ and $47 \%$ for the Kattoli and Kumira respectively. In both year and study area graduation level education was very few (Figure 4).

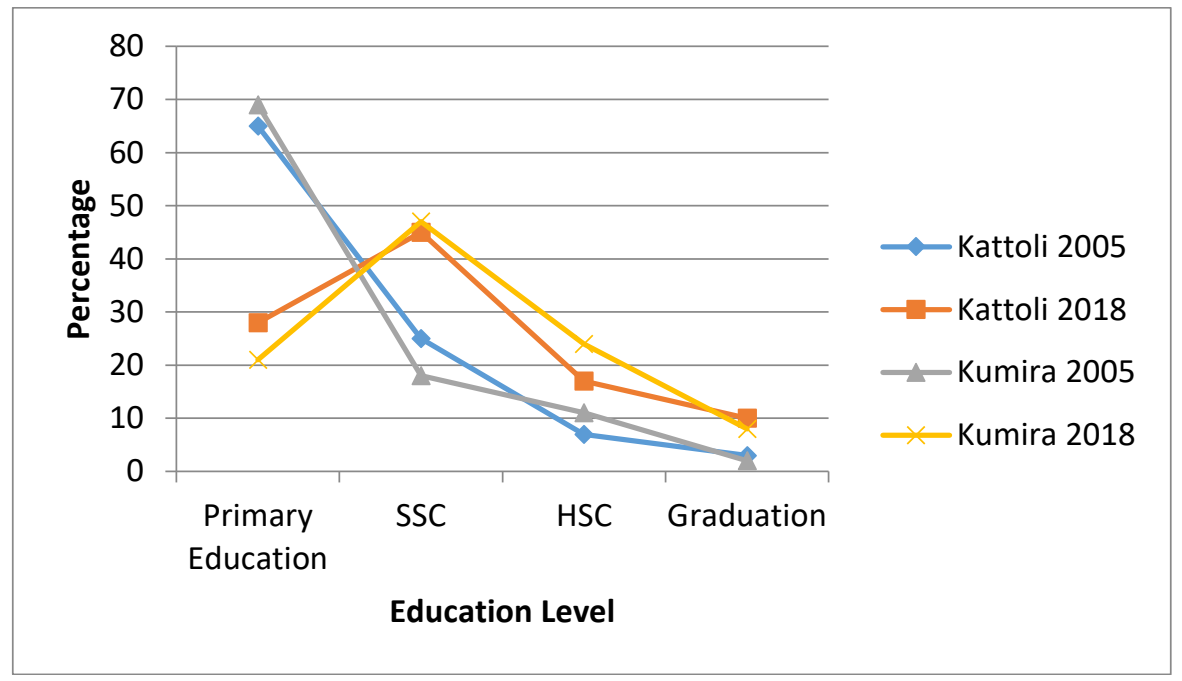

Figure 4: Education status of fisher in Kattoli and Kumira villages

\section{Human Resources}

According to study, the total population of Kattoli were 867, out of which about $52 \%$ male and 48\% female in 2005 and about 57\% male and $43 \%$ female in 2018. In Kumira village, total population was 670 , out of which about $60 \%$ male and $40 \%$ female in 2005 and about $55 \%$ male and $45 \%$ female in 2018 (Figure 5).

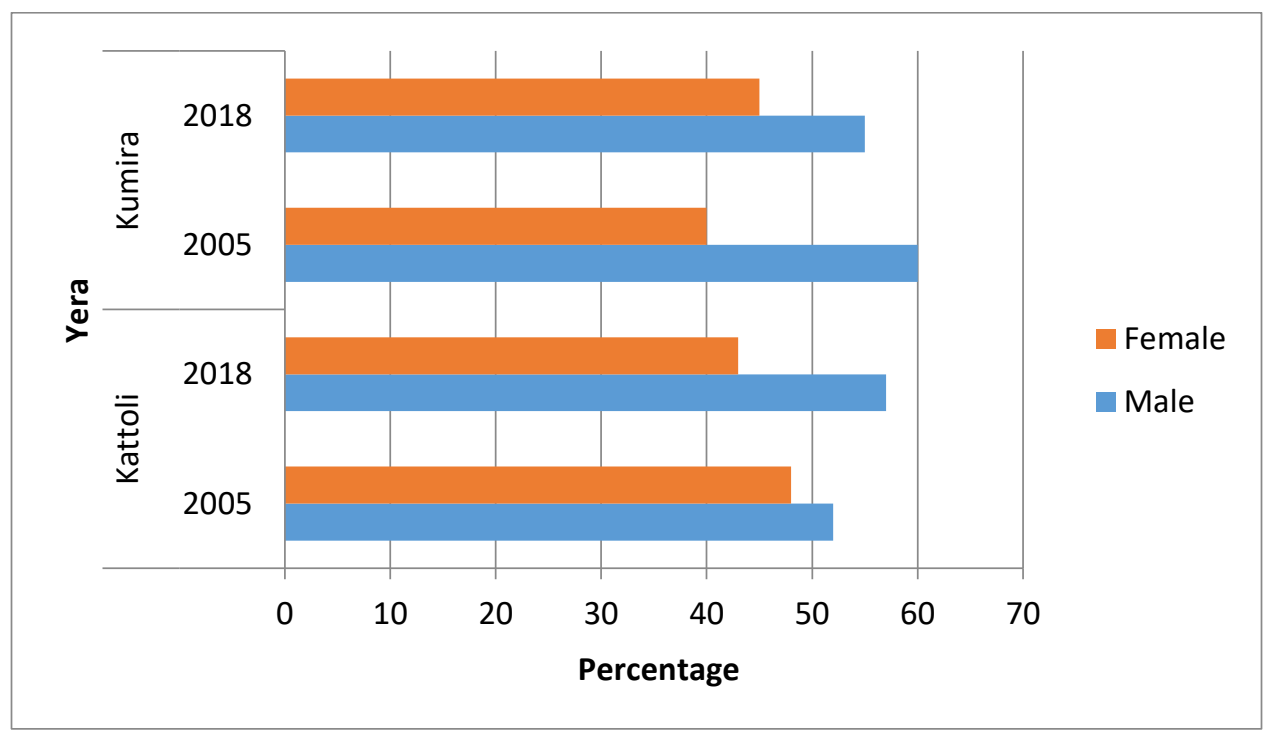

Figure 5: Human resources in Kattoli and Kumira villages

\section{Housing Condition}

There were 160 household in Kattoli and 78 household in Kumira of which tin shed and bamboo made house hold were the common feature. Where, in 2018 in Kattoli there are 237 household has tin shed and 86 household has concrete made housing along with, in Kumira 167 household has tin shed and 73 household has concrete made housing (Figure 6). 


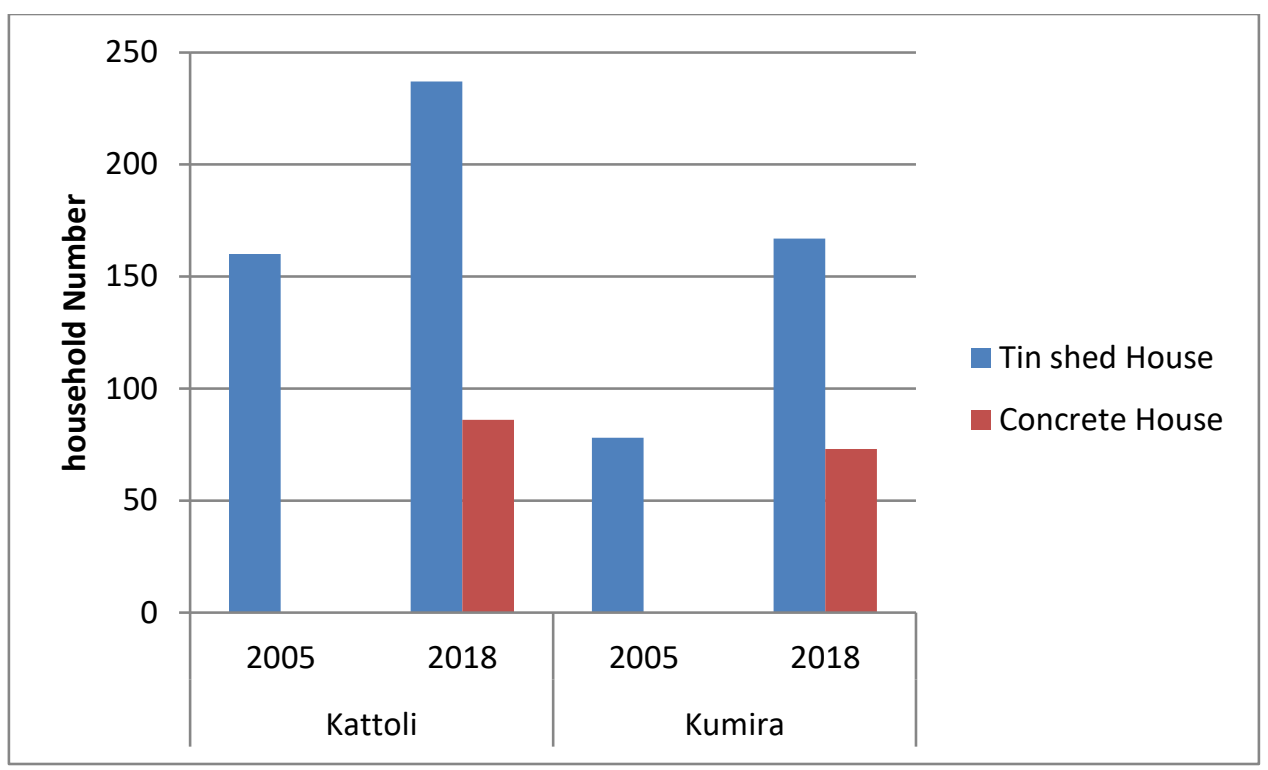

Figure 6: Housing condition in Kattoli and Kumira villages

\section{Water and Sanitation}

No deep tub-well seen whereas 27 shallow tube well in Kattoli and 15 in Kumira for drinking water found in the study area in 2005. Where, in 2018 whereas 155 shallow tube-well and 15 deep tube-well in Kattoli and 135 shallow tube-well and 12 deep tube-well found in Kumira for drinking water supply (Figure 7).

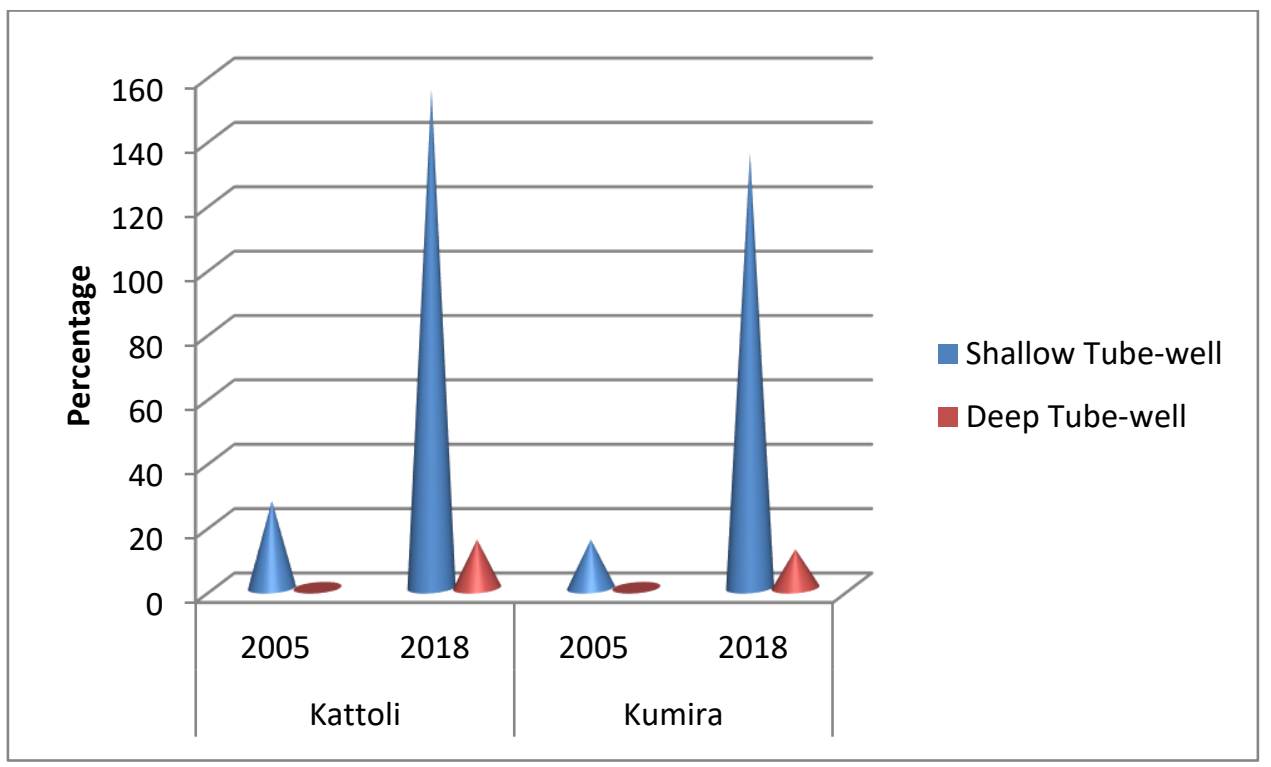

Figure 7: Water supply and sanitation facilities in Kattoli and Kumira villages

\section{Entertainments}

In 2005 only $20 \%$ family has electricity, 5\% family has Television, 50\% family has Cassette player/Radio, $4 \%$ family has VCR/CD Player, $1 \%$ family has mobile phone in Kattoli. Only $25 \%$ family has electricity, 9\% family has Television, $45 \%$ family has Cassette player/Radio, $12 \%$ family has VCR/CD Player, 2\% family has mobile phone in Kumira. But in course of time in 2018, 
$100 \%$ family has electricity, $79 \%$ family has Television, $100 \%$ family has Cassette player/Radio, $60 \%$ family has VCR/CD Player, $100 \%$ family has mobile phone in Kattoli. Whereas, $100 \%$ family has electricity, $91 \%$ family has Television, $100 \%$ family has Cassette player/Radio, $86 \%$ family has VCR/CD Player, 100\% family has mobile phone in Kumira (Figure 8).

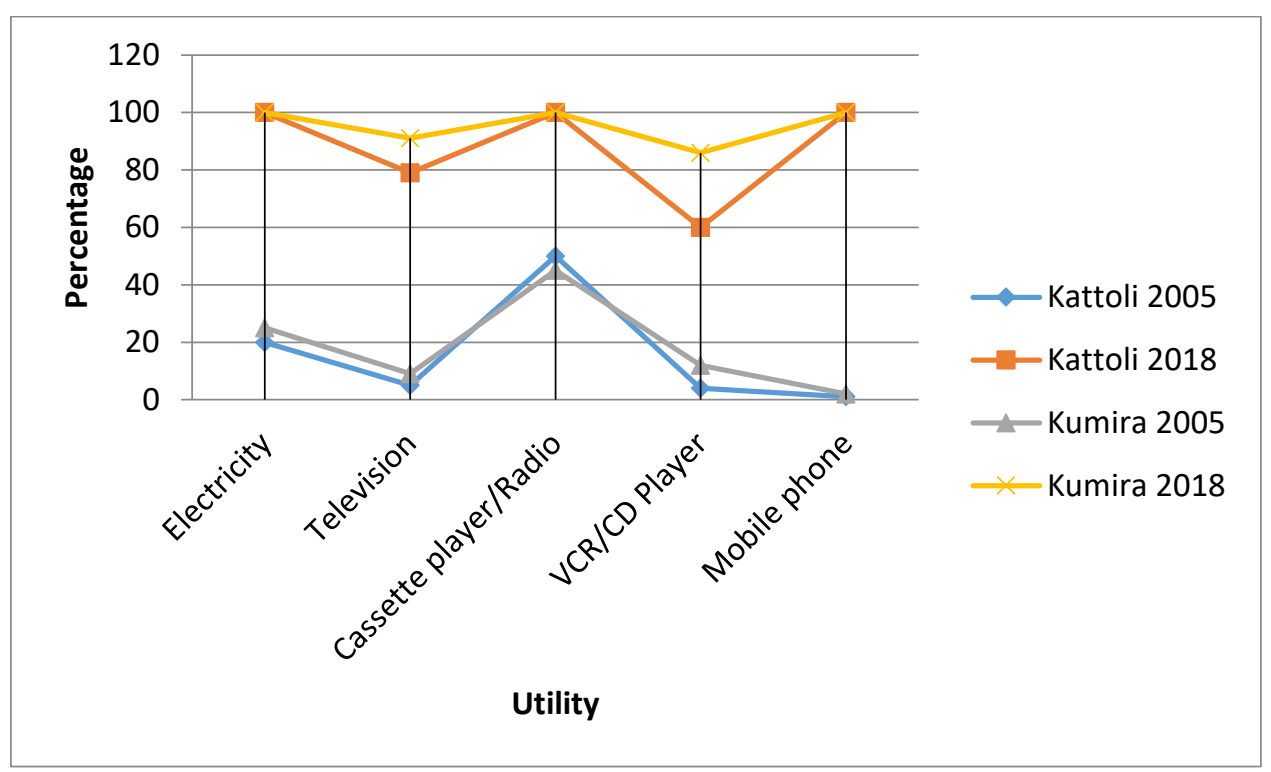

Figure 8: Entertainments and utility facilities in Kattoli and Kumira villages

\section{Seasonal Calendar}

Seasonal calendar provides a general picture of important environmental and socioeconomic trends throughout the year. The information was assimilated, synthesized and triangulated and finally a seasonal calendar of livelihood activities of the study area was formulated (Figure 9).

\begin{tabular}{|c|c|c|c|c|c|c|c|c|c|c|c|c|}
\hline $\begin{array}{l}\text { Month } \\
\text { Item }\end{array}$ & $\begin{array}{c}\text { Baishak } \\
\text { (April- } \\
\text { May) }\end{array}$ & $\begin{array}{l}\text { Jaistha } \\
\text { (May- } \\
\text { June) }\end{array}$ & $\begin{array}{l}\text { Ashar } \\
\text { (June- } \\
\text { July) }\end{array}$ & $\begin{array}{l}\text { Srabon } \\
\text { (July- } \\
\text { Aug) }\end{array}$ & $\begin{array}{l}\text { Bhadra } \\
\text { (Aug- } \\
\text { Sept.) }\end{array}$ & $\begin{array}{c}\text { Ashwin } \\
\text { (Sept.- } \\
\text { Oct.) }\end{array}$ & $\begin{array}{l}\text { Kartik } \\
\text { (Oct.- } \\
\text { Nov.) }\end{array}$ & $\begin{array}{c}\text { Aghrahion } \\
\text { Nov.- } \\
\text { Dec.) }\end{array}$ & $\begin{array}{l}\text { Poush } \\
\text { (Dec. } \\
\text { Jan) }\end{array}$ & $\begin{array}{l}\text { Magh } \\
(\text { Jan- } \\
\text { Feb) }\end{array}$ & $\begin{array}{c}\text { Falgun } \\
\text { (Feb- } \\
\text { Mar) }\end{array}$ & $\begin{array}{c}\text { Chaitra } \\
\text { (Mar- } \\
\text { Apr) }\end{array}$ \\
\hline Agriculture & & & & & & & & & & & & \\
\hline $\begin{array}{l}\text { Hilsha } \\
\text { fishing }\end{array}$ & & & & & & & & & & & & \\
\hline $\begin{array}{l}\text { Crab } \\
\text { Fishing }\end{array}$ & & & & & & & & & & & & \\
\hline $\begin{array}{l}\text { Other } \\
\text { fishing } \\
\text { (behudi net) }\end{array}$ & & & & & & & & & & & & \\
\hline $\begin{array}{l}\text { Vegetable } \\
\text { (yard) }\end{array}$ & & & & & & & & & & & & \\
\hline $\begin{array}{l}\text { Rainy } \\
\text { season }\end{array}$ & & & & & & & & & & & & \\
\hline Poultry & & & & & & & & & & & & \\
\hline $\begin{array}{l}\text { Human } \\
\text { Disease }\end{array}$ & & & & & & & & & & & & \\
\hline Cyclone & & & & & & & & & & & & \\
\hline
\end{tabular}




\begin{tabular}{|l|l|l|l|l|l|l|l|l|l|l|l|l|}
\hline $\begin{array}{l}\text { Water } \\
\text { logging }\end{array}$ & & & & & & & & & & & & \\
\hline Daily labour & & & & & & & & & & & & \\
\hline Livestock & & & & & & & & & & & & \\
\hline Fish trading & & & & & & & & & & & & \\
\hline Service & & & & & & & & & & & & \\
\hline
\end{tabular}

Figure 9: Generalized seasonal calendar of two villages.

\section{Mobility Chart}

Mobility chart was prepared for knowing the areas where the people goes for their needs and also where they go frequently and their connection with the urban areas. The common mobility chart of the two villages is given here (Figure 10).

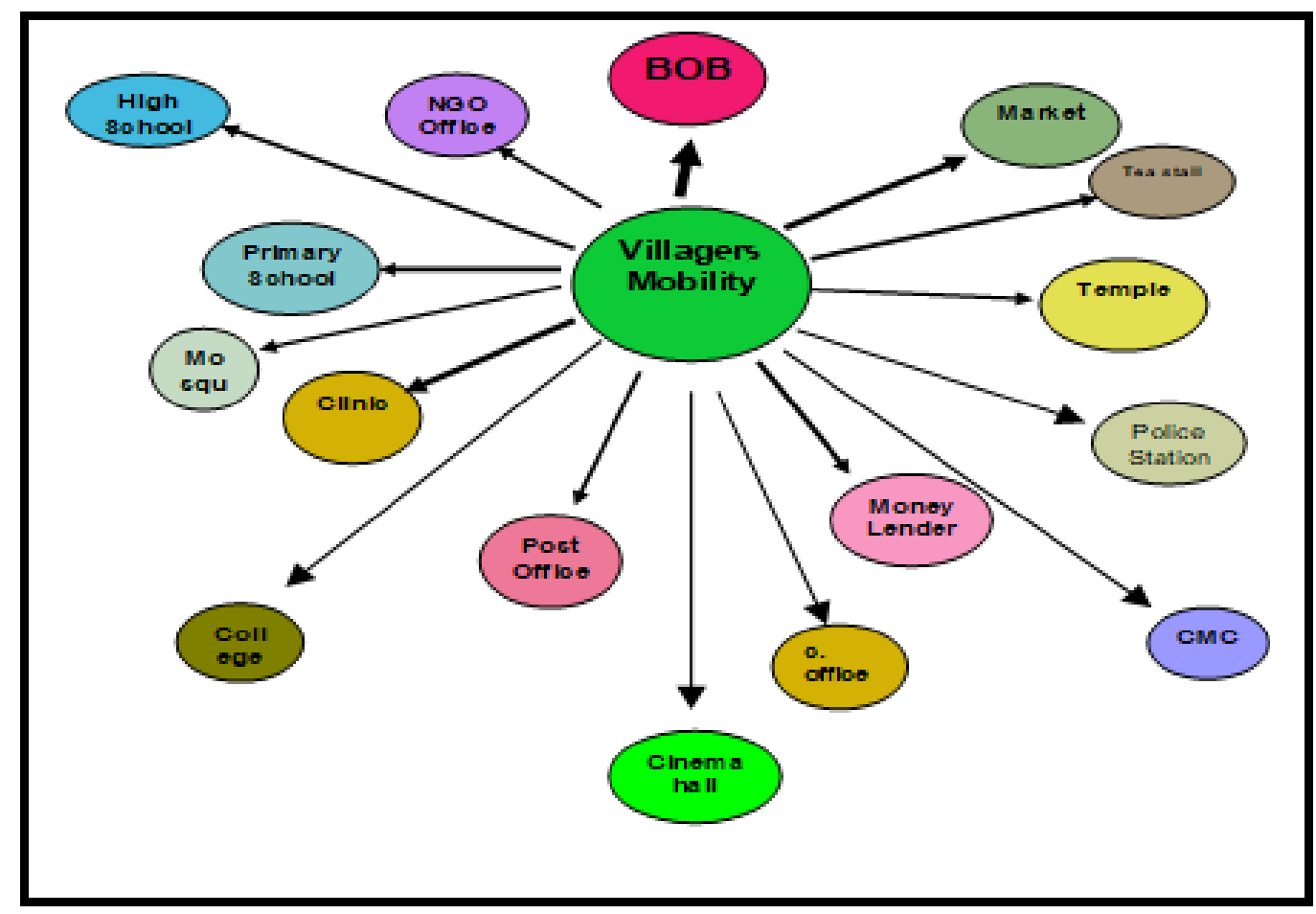

Figure 9: Mobility chart of the villagers.

Figure 10: The common mobility chart of the two villages

\section{Economic Classifications}

\section{Rich}

They have their own house, boats, nets, shops and some of them have goats, hens, ducks, cow etc. most rich households are fish traders. The rich households have an income of 1,00,000-1,50,000 Tk/year.

\section{Middle class}

Most middle classes households have their own house and own nets but most them do not have own boats. They mainly rely on fishing. Their rarely income is 50,000-60,000 Tk/year. 


\section{Poor}

They have own nets but no boats. Some of them work as a daily labour in to other boats. Yearly income 25,000 - 35,000 Tk/year (Figure 11).

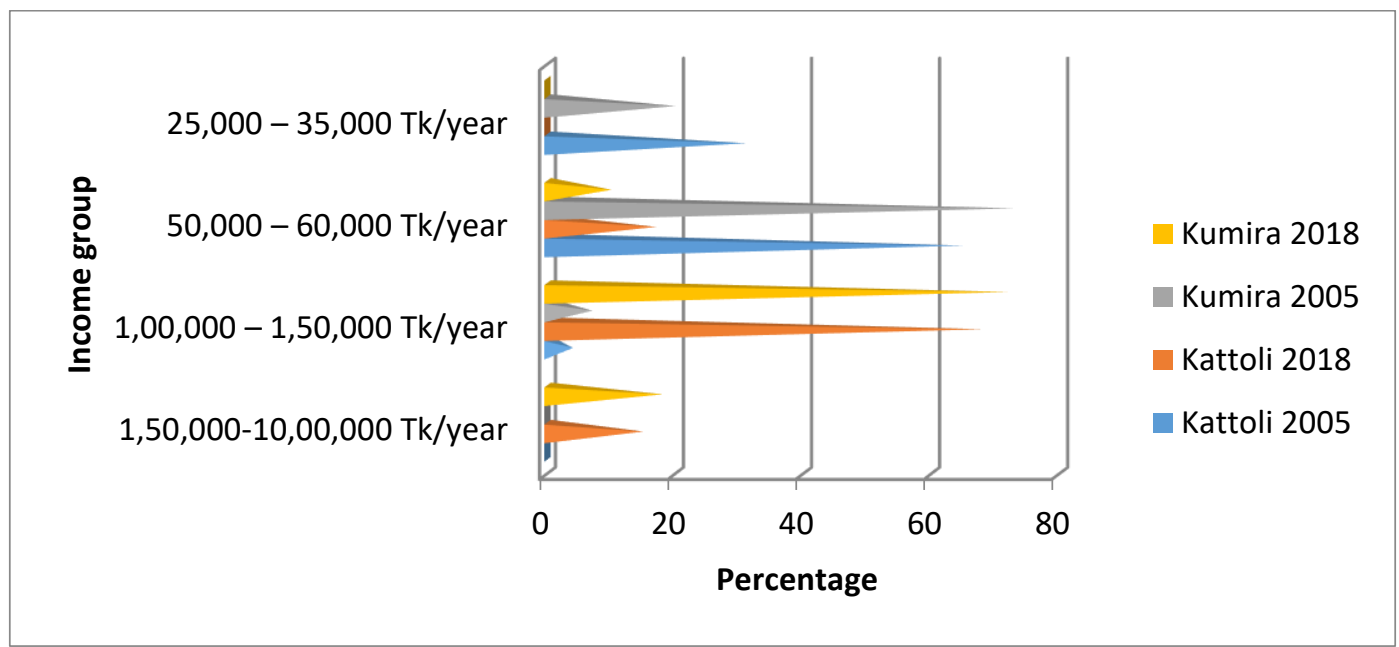

Figure 11: Economic classification of the two villages

\section{Health}

In 2005, for Kattoli village, about 34\% patient used to visit to MBBS doctor and $66 \%$ went quack doctor and in 2018, about $86 \%$ patient used to visit to MBBS doctor and 14\% went quack doctor. In case of Kumira village in 2005, about $39 \%$ patient used to visit to MBBS doctor and $61 \%$ went quack doctor and in 2018, about $92 \%$ patient used to visit to MBBS doctor and $8 \%$ went quack doctor (Figure 12).

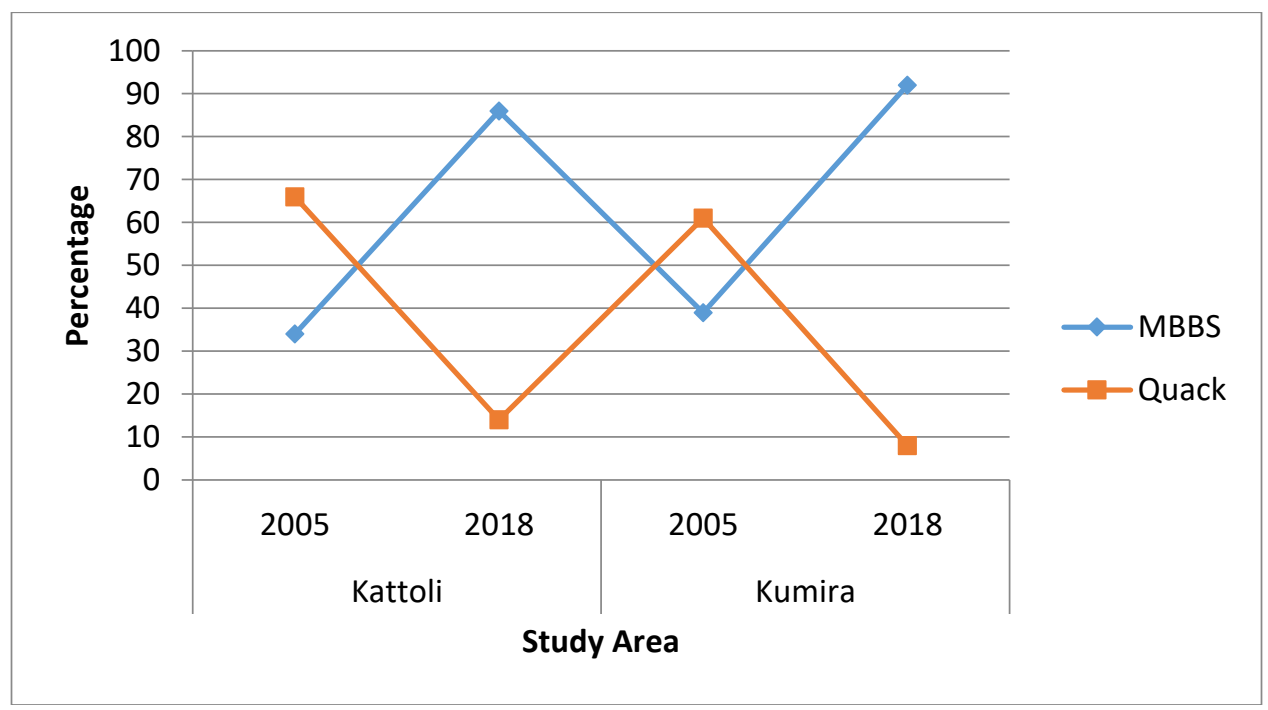

Figure 12: Health facilities in Kattoli and Kumira villages

\section{Nutrition}

In 2005, for Kattoli village, about $61 \%$ fisher had taken three meals daily and in $2018,84 \%$ has three meals in daily basis where, in 2005 , for Kumira village, about $53 \%$ fisher had taken three meals daily and in 2018, 82\% has three meals in daily basis (Figure 13). 


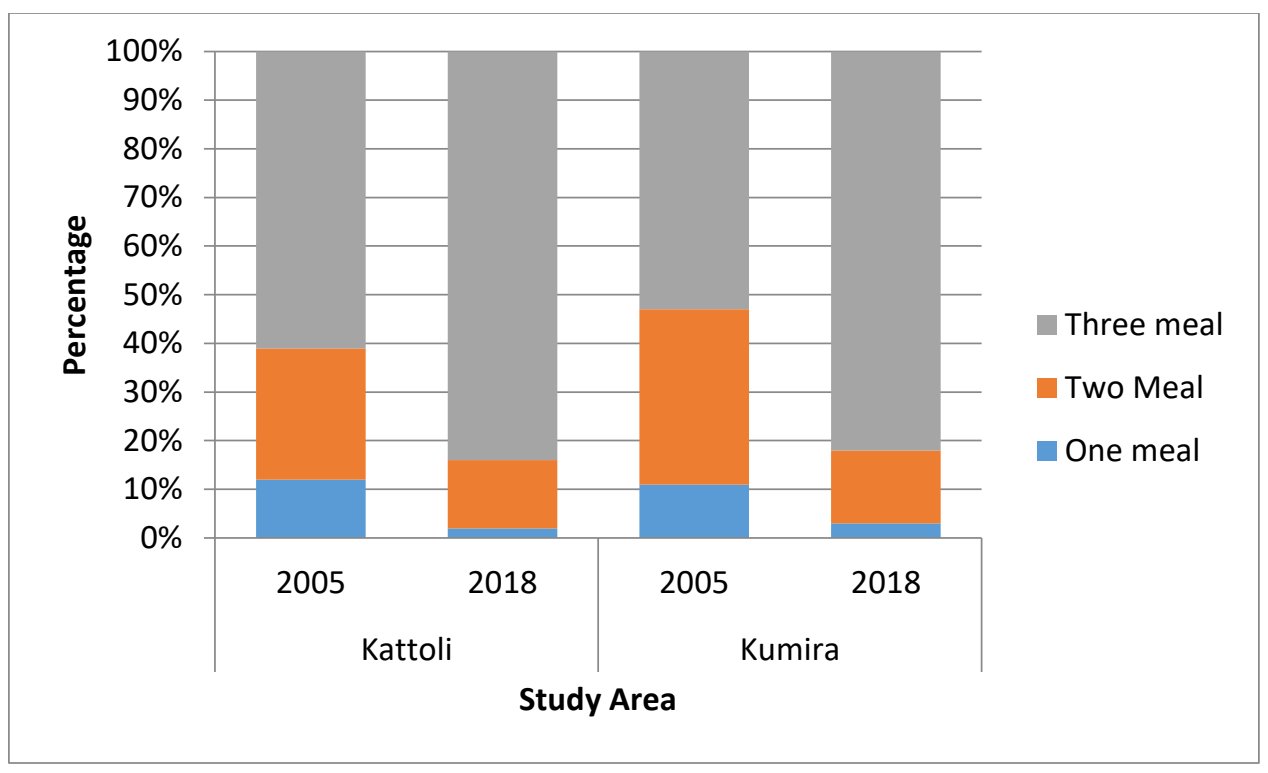

Figure 13: Nutrition and daily meal allowance of fisher in Kattoli and Kumira villages

\section{Wealth Ranking}

In the community we identified four groups of wealth ranking, they are rich, middle class, poor and extreme poor. Rich household have their own land, brick build house, boats, nets, television, radio etc. Some have shop and also have kitchen room, tube-well, cattle's goats, hens, ducks and working in foreign country. They eat nutritious food, sometimes arrange improve food and wear well clothe. They are less affect by disease and health is good. They have their own house, boats, nets, shops and some of them have goats, hens, ducks, cow etc. most rich households are fish traders. The rich households have an income of 1,00,000 - 1,50,000 Tk/year. Their number were 3-4. Most middle classes households have their own house and own nets but most them do not have own boats. They mainly rely on fishing. Their rarely income is 50,000 - 60,000 Tk/year. They have own nets but no boats. Some of them work as a daily labour in to other boats. Yearly income 25,000 - 35,000 Tk/year. They have no land and no nets. They lives from hand to mouth. Per capita annual income $15000-20000$ Tk/yaer.

\section{Discussions}

It was found, in 2005 Kattoli and Kumira has largest portion of the 20-30 age group, 55\% and 58\% respectively and according to survey, in 2018 it was found 30-40 age group is dominant as 50\% and $46 \%$ of total fisher population. Among 50 farmers, it was found that the highest proportions (36\%) of fish farmer were middle aged (31 years-40 years) and above 50 years was the lowest (14\%) Adhikary et al. (2018). Kaiya et al, (1987) found that fish culture efficiency varied with the age and number of owners of pond in Tangail district. Vaumik et al. (2017) stated that, 30\% farmers were 31-35 years old, 31\% were between 36-40 in Lalmonirhat district. Sharif et al. (2015) concluded $85 \%$ farmer has the age of 40 and above in Jessore district. Islam et al. (2015) founded in sundarban the maximum age level was 20-30 years old. Islam et al. (2014) revealed $44 \%$ farmer had a age level 31-40 years as well as Asif and Habib (2017) research found the 38\% people has an age group of 51-60 years which is similar with the present study. The total family number of the study area is 580 in Kattoli and 550 in Kattoli in 2005 whereas, total family number of the study area is 637 in Kattoli and 623 in Kattoli in 2018. No family number data is available until 
this present study in study area. There are about 65\% Hindu communities and 35\% Muslim in Kattoli where Kumira comprises $80 \%$ Hindu (jolodash) and 20\% Muslim in 2005 along with there are about $45 \%$ Hindu communities and 55\% Muslim in Kattoli where Kumira comprises $40 \%$ Hindu (jolodash) and 60\% Muslim in 2018. Khatun et al. (2013) observed in his study in Charbata in Noakhali district that $82 \%$ of fish farmers were Muslims and $18 \%$ were Hindus. Sharif et al. (2015) observed that all of fish farmers (100\%) were Muslims that relates with my study. Asif et al. (2015); Hossain et al. (2015); Islam et al. (2014) and Islam et al (2015) also found the similar results. The number of primary education obtainer in Kattoli and Kumira in 2005 were significant and the percent were $65 \%$ and $69 \%$ respectively where other education group were negligible to mention. In comprises, 2018 has a dynamic change over education where, the largest education group were, Secondary education obtainer as $45 \%$ and $47 \%$ for the Kattoli and Kumira respectively. In both year and study area graduation level education was very few. Fish farmer had $44 \%$ education up to primary level, $24 \%$ fish farmer had secondary education, $18 \%$ had S.S.C passed and 14\% had no education Adhikary et al. (2018). Zaman et.al, (2006) found that 23.3\% farmers were illiterate whereas $14.4 \%, 8.9 \%$ and $6.7 \%$ were educated up to primary, secondary and higher secondary or above level respectively in Rajshahi district. Asif et al. (2015) 46\% of traders have institutional education; Asif and Habib (2017) stated 36\% had primary level, $42 \%$ had secondary level (up to X), 10\% had S.S.C. level, $4 \%$ had H.S.C. level and $4 \%$ had bachelor level of education. Hossain et al. (2016b) found most of the respondents (40\%) are illiterate. In Meherpur another study found 16\% farmer had primary level, 36\% had secondary level, $20 \%$ had S.S.C. level, 14\% had H.S.C. level, and 6\% had bachelor level of education Islam et al. (2017a). Hossain et al. (2015) mentioned only $18.33 \%$ are secondary educated in Dinajpur district. Rahman et al. (2017) mentioned that, 33\% of the contact farmers had up to secondary level of education (S.S.C) and only 7\% of the contact farmers had masters' degree. According to present study, the total population of Kattoli were 867, out of which about 52\% male and $48 \%$ female in 2005 and about $57 \%$ male and $43 \%$ female in 2018. In Kumira village, total population was 670 , out of which about $60 \%$ male and $40 \%$ female in 2005 and about $55 \%$ male and $45 \%$ female in 2018 . A field survey report show that in the study area $70 \%$ were male and $30 \%$ were female Hossain et al. (2016b). Among the fry collectors $66 \%$ was male and $34 \%$ was female Islam et al. (2015). There were 160 household in Kattoli and 78 household in Kumira of which tin shed and bamboo made house hold were the common feature. Where, in 2018 in Kattoli there are 237 household has tin shed and 86 household has concrete made housing along with, in Kumira 167 household has tin shed and 73 household has concrete made housing. About $69 \%$ households of the fish farmer were tinshed, 23\% katcha and only 8\% half building (Adhikary et al., 2018). Rahman (2003) reported that $70 \%$ of were katcha, while $21 \%$ were semi-pucca and only $9 \%$ were pucca in Gazipur district. Ahmed (2001) also found that $62 \%$ of katcha housing structure of prawn farmers in Mymensingh area. Asif and Habib (2017) stated around 88\% had concrete house in Jhikargachha upazila, Jessore which is not similar with the study. Sharif et al. (2015) found 54\% farmers used semi pucca, $19 \%$ of fish farmers used to live pucca houses and rest of $27 \%$ farmers used to live earthen houses in Chaugachha, Jessore. Islam et al. (2014) revealed full katcha (17\%) houses were few, while the semipucca (40\%) and pucca (43\%) houses were more abundant. No deep tub-well seen whereas 27 shallow tube well in Kattoli and 15 in Kumira for drinking water found in the study area in 2005. Where, in 2018 whereas 155 shallow tube-well and 15 deep tube-well in Kattoli and 135 shallow tube-well and 12 deep tube-well found in Kumira for drinking water supply. Hundred percentage of the studied fishermen used tube-wells' water for drinking purposes and among them $64 \%$ fishermen had own tube-well and 36\% used neighbors tube-well (Adhikary et 
al., 2018). This is contradictory with the present study. Kabir et.al, (2012) found that the highest (100\%) fishermen of the Old Brahmaputra River used tube-well water for drinking purposes, among them $40 \%$ had their own tube-well, 50\% used shared tube-well and remaining $10 \%$ used neighbors tube-well. Same study conducted by Ali et al. (2016); Asif et al. (2015); Asif and Habib (2017); Hossain et al. (2015); Sharif et al. (2015); Vaumik et al. (2017); Zaman et al. (2017); Shabuj et al. (2016a) and Razeim et al. (2017) also they have found the similar results. In 2005 only $20 \%$ family has electricity, $5 \%$ family has Television, $50 \%$ family has Cassette player/Radio, $4 \%$ family has VCR/CD Player, $1 \%$ family has mobile phone in Kattoli. Only $25 \%$ family has electricity, $9 \%$ family has Television, $45 \%$ family has Cassette player/Radio, $12 \%$ family has VCR/CD Player, 2\% family has mobile phone in Kumira. But in course of time in 2018, 100\% family has electricity, 79\% family has Television, 100\% family has Cassette player/Radio, 60\% family has VCR/CD Player, 100\% family has mobile phone in Kattoli. Whereas, $100 \%$ family has electricity, $91 \%$ family has Television, $100 \%$ family has Cassette player/Radio, $86 \%$ family has VCR/CD Player, and 100\% family has mobile phone in Kumira. Asif et al. (2015) revealed, among them $93 \%$ traders have television, $5 \%$ house consist radio and another $2 \%$ house no instrument for entertainment in their house. Sharif et al. (2015 stated that $99 \%$ farmers use mobile phone and only $1 \%$ has no mobile phone in a upazila in Jessore and these studies is similar with the present study. Seasonal calendar provides a general picture of important environmental and socioeconomic trends throughout the year. No seasonal calendar data was available until now for the study area. The rich households have an income of 1,00,000 - 1,50,000 Tk/year. Most middle classes has rarely income is 50,000 - 60,000 Tk/year. Yearly Poor has income 25,000 - 35,000 Tk/year in the present study. Majority of farmers (48\%) had income around BDT 10000-20,000 per month before fish farming and after fish farming 41\% had above BDT 20,000-30,000 per month and income level of fish farmers increased and no one had income below BDT 10,000 per month. Average income of fish farmer was 15,000-25,000 per month (Adhikary et al., 2018). Okorie (2000) reported that average monthly income from cage culture was BDT 2250 (USD\$30). The highest percentage (34\%) fish farmers earned BDT 75,000 to 1,00,000 per year. It was higher than the national average BDT 28,430 (BBS, 2004). The present findings of annual income of fish farmers correspond well with the findings of Rahman et al. (2012) in Noakhali district. Khan et al. (1986) stated that levels of family income are important economic factor affecting utilization of pond fish farming in Mymensingh district. The fishermen community of two villages has limited livelihood opportunities, which is very much similar with the finding of the (Blow field et al., 1995). But present investigation also showed that the socioeconomic status of kattoli was somewhat better than Kumira though it is below poverty level (monthly income less than Tk. 3000). In 2005, for Kattoli village, about $34 \%$ patient used to visit to MBBS doctor and $66 \%$ went quack doctor and in 2018, about $86 \%$ patient used to visit to MBBS doctor and $14 \%$ went quack doctor. In case of Kumira village in 2005, about $39 \%$ patient used to visit to MBBS doctor and $61 \%$ went quack doctor and in 2018, about $92 \%$ patient used to visit to MBBS doctor and $8 \%$ went quack doctor. Respectively $52 \%$ and $28 \%$ fish farmer took medical facility from unskilled, nonprofessional village doctor and kabiraj. Fourteen percentages took medical facility from upazilla health complex and only $6 \%$ took medical facility from MBBS doctor (Adhikary et al., 2018). Ali et.al, (2008) found that $46 \%$ of the farmers received health service from village doctors, $18 \%$ from upazila health complex, $14 \%$ from district hospital and 20\% from MBBS doctors in Rajshahi district. Asif et al. (2015); Asif and Habib (2017); Hossain et al. (2015); Sharif et al. (2015); Vaumik et al. (2017) and Islam et al. (2014) have had the similar results with present study. In 2005, for Kattoli village, about $61 \%$ fisher had taken three meals daily and in 2018, $84 \%$ 
has three meals in daily basis where, in 2005, for Kumira village, about $53 \%$ fisher had taken three meals daily and in 2018, 82\% has three meals in daily basis. One time of the day they starved. Little number (12\%) could take 3 times meal per day (Adhikary et al., 2018). This is not following the present study. Siddika et al. (2016) reveals their study in Jessore district and found that maximum labor took nutrias food. After fish farming the highest number (57\%) of fish farmer could eat 3 times meal per day. Lowest number (16\%) could take 1 time meal per day due to their lack of technical knowledge, multiple ownership, pouching, non-availability of fry and fertilizer etc. They have their own house, boats, nets, shops and some of them have goats, hens, ducks, cow etc. most rich households are fish traders. The rich households have an income of 1,00,000 1,50,000 Tk/year. Their number were 3-4. Most middle classes households have their own house and own nets but most them do not have own boats. They mainly rely on fishing. Their rarely income is 50,000 - 60,000 Tk/year. They have own nets but no boats. Some of them work as a daily labour in to other boats. Yearly income 25,000 - 35,000 Tk/year. They have no land and no nets. They lives from hand to mouth. Per capita annual income $15000-20000$ Tk/yaer. Sultana et al. (2015) stated the similar resource aboundance in their study area.

\section{References}

[1] Ripon Kumar Adhikary, Saurabha Kar, Al Faruk, Amir Hossain, Md. Nurul Mahmud Bhuiyan and Abdulla-Al-Asif (2018), "Contribution of aquaculture on livelihood development of fish farmer at Noakhali, Bangladesh", Asian-Australasian Journal of Bioscience and Biotechnology, 3 (2):106121.

[2] Nesar Ahmed (2001), "Socio-economic aspects of freshwater prawn culture development in Mymensingh, Bangladesh.” A report prepared for ICLARM.

[3] Ali MH, MD Hossain, ANGM Hasan and MA Bashar, (2008), "Assessment of the livelihood status of the fish farmers in some selected areas of Bagmara upazilla under Rajshahi district", Journal of Bangladesh Agricultural University, 6: 367-374.

[4] Md. Munsur Ali, Abdulla-Al-Asif, Md. Azharul Islam Shabuj, SuvashisVaumik, Md. Abu Zafar, B.M. Newaz Sharif (2016), "Status of polyculture Pangasius hypophthalmus with carps in Jhikargacha Upazila of Jessore District, Bangladesh", International Journal of Fisheries and Aquatic Studies, 4: 423-430.

[5] Abdulla-Al-Asif and Md. Ahsan Bin Habib (2017)," Socio-economic condition of fish farmers of Jhikargachha upazila in Jessore district, Bangladesh", Asian Journal of Medical and Biological Research, 3: 462-475. doi: 10.3329/ajmbr. v3i4.35337

[6] Abdulla-Al-Asif, Md. Abdus Samad, Md. Habibur Rahman, Md. Almamun Farid, Syeda Maksuda Yeasmin and B.M. Shahinur Rahman (2015), "Socio-economic condition of fish fry and fingerling traders in greater Jessore region, Bangladesh", International Journal of Fisheries and Aquatic Studies, 2: 290-293.

[7] BBS (2004), "Statistical yearbook of Bangladesh", Bangladesh Bureau of Statistics, Ministry of Planning, Government of the People's Republic of Bangladesh, Dhaka.

[8] Blowfield, M.E. (1995), "Socio-economic methodologies for coastal fishing communities in Bangladesh, Dhaka"

[9] Chong, Kee-Chai, Islam,N. and Begum, M. (1991), "Analysis of the constructions to an potential and opportunities for expanded fisheries production in Bangladesh." Field document on institutional strengthening in the fisheries sector, Bangladesh. Ministry of Fisheries and Livestock, UNDP, FAO, BGD/87/045/91/07, Dhaka, Bangladesh.

[10] Md. Arman Hossain, Abdulla-Al-Asif, Md. Abu Zafar, Md. Tanvir Hossain, Md. Shahin Alam, Md. Ashraful Islam (2015), "Marketing of fish and fishery products in Dinajpur and livelihoods of the fish retailers", International Journal of Fisheries and Aquatic Studies, 3: 86-92. 
[11] Md. Zelal Hossain, Anik Pal, Md. Amit Hasan, Md. Suman Parvej, Nazneen Nahar and AbdullaAl-Asif (2016b), "Nutritional status and socio-demographic characteristics of the people of southwest coastal region in Bangladesh", Asian-Australasian Journal of Bioscience and Biotechnology, 1: 323-332.

[12] FM Kamrul Islam, Abdulla-Al-Asif, Meraz Ahmed, Md Samadul Islam, Baadruzzoha Sarker, Md Abu Zafar and Mizanur Rahman (2017a), "Performances of resource poor households in aquaculture practices in sadar upazila, Meherpur, Bangladesh”, International Journal of Fisheries and Aquatic Studies, 5: 281-288.

[13] Md. Anisul Islam, Abdulla-Al-Asif, Md. Abdus Samad, B. M. Shahinur Rahman, Md. Habibur Rahman, Akhery Nima and Syeda Maksuda Yeasmin (2014), "Socio-economic conditions of the fish farmers in Jessore, Bangladesh", International Journal of Business, Social and Scientific Research. 2: 153-160.

[14] Md. Monirul Islam, Abdulla-Al-Asif, Suvashis Vaumik, Md. Abu Zafar, BM Newaz Sharif, Md. Habibur Rahman, Sayeed Shahriyar (2015), "Socio economic status of fry collectors at Sundarban region", International Journal of Fisheries and Aquatic Studies, 3: 89-94.

[15] Islam, M.S., and Elahi (1993), "Study of catch composition of behundi net in relation to some ecological parameters in the Naf river estuary. Marine Fisheries Survey, Management and Development Project, Cox's Bazar, Bangladesh(mimeo)."

[16] M. Serajul Islam (1994), Socioeconomic status of marine fishermen and their upliftment. Proceeding of a workshop on "Sustainable Development of Marine Fisheries resources in Bangladesh", Cox's Bazar, Bangladesh. 58-64pp.

[17] M. Serajul Islam (1994), Socioeconomi status of marine fishermen and their upliftment. Proceeding of workshop on "Sustainable Development of Marine Fisheries resources in Bangladesh", Cox's Bazar, Bangladesh.58-65pp.

[18] K.M. Rejwan Kabir, Ripon Kumar Adhikary, M. Belal Hossain and Maruf Hossain Minar (2012), "Livelihood Status of Fishermen of the Old Brahmaputra River, Bangladesh", World Applied Science Journal, 16: 869-873.

[19] Kaiya MKU, MFA Mollah and MS Islam (1987), "Survey of pond resources of Mirzapur Upazila under Tangail district", Bangladesh Journal of Fisheries, 10: 37-43.

[20] Khan M.S. (1986), "Socio-economic factors in the development of fisheries", Bangladesh Journal of Agricultural Economics, 10: 43-47.

[21] Khan, M.G. (1994), "Present Status and Future Plan for Sustainable Marine Resources Development." Proceeding of a workshop on "Sustainable Development of Marine Fisheries resources in Bangladesh", Cox's Bazar, Bangladesh. 30-37pp.

[22] Khan, M.G. (1982), "Pilot survey of set bag net fishery of Bangladesh", BOBP/WP/34.Rome.26pp.

[23] Khan, M.G. (1993), "Bongoposhagoer Matshya Sampad O Tar Arthonaitik", Guruthya, MatshyaPasho sampad Barta No.6.

[24] Khatun S, Adhikary RK, Rahmanh M, Sikder MNA, Hossain MB (2013), "Socioeconomic status of pond fish farmers of Charbata, Noakhaliu, Bangladesh", International Journal of Life Science, Biotechnology and Pharmacology Research. 2:356-365.

[25] Mustafa, M.G., Khan, M.G., Islam. M.S., Sada, M.N., and Chowdhury, Z.A. (1994), "Biosocioeconomic Assessment of the Effect of the Estuarine Set Bag Net on the Marine Fisheries of Bangladesh", Bay of Bengal Program/WP/94.28pp.

[26] Okorie PU 2000. "Socio-economic appraisal of cage culture Nogutake, Nigera. Department of Animal and Environmental Biology", ltrw State University. IMB., Owerri, Nigeria.

[27] Hafzur Rahman, Jabed Ali Mirza, Amir Hossain, Abdulla-Al-Asif, Emdadul Haq, Palas Chwakravorty and Mizanur Rahman (2017), "Economics of fish production in paddy fields in Bangladesh", Asian Journal of Medical and Biological Research, 3: 379-390. doi: 10.3329/ajmbr. v3i3.34528 
[28] Rahman M, MF Tazim, SC Dey, AKMS Azamand and MR Islam (2012), "Alternative livelihood options of fishermen of Nijhum Dwip under Hatiya upazila of Noakhali district, Bangladesh”, Asian Journal of Rural Development, 2: 24-31.

[29] Rahman MM (2003), "Socio-economic aspects of carp culture development in Gazipur, Bangladesh", M.S. thesis, Department of Fisheries Management, Bangladesh Agricultural University, Mymensingh. 72 pp.

[30] Md. Abu Razeim, Md. Golam Farouque, Md. Asaduzzaman Sarker, Abdulla-Al-Asif and Meraz Ahmed (2017), "Attitude of farmers towards Pangas farming for their livelihood improvement", Asian-Australasian Journal of Bioscience and Biotechnology, 2: 106-119.

[31] Md. Azharul Islam Shabuj, Abdulla-Al-Asif, Omar Faruq, Md. Rafiqul Bari, Md. Anisur Rahman (2016a), "Brood stock management and induced breeding of Thai Pangus (Pangasius hypophthalmus) practiced in the hatcheries of Jessore region, Bangladesh", International Journal of Business, Social and Scientific Research, 4: 235-246.

[32] BM Newaz Sharif, Abdulla-Al-Asif, Suvashis Vaumik, Md. Abu Zafar, Md. Monirul Islam, Md. Abdus Samad (2015), "Socio-economic condition of fish farmer and trader at the village of Pitamborpur in Chaugachha upazilla in Jessore, Bangladesh", International Journal of Fisheries and Aquatic Studies, 3: 212-217.

[33] Tahmina Siddika, Ripon Kumar Adhikary, Md. Hasan-Uj-Jaman, Shoumo Khondoker, Nazia Tabassum, Md. Farid Uz Zaman (2016), "Socio economic conditions of the hatchery labors in Chanchra area of Jessore district in Bangladesh", Agriculture, Forestry and Fisheries, 5: 30-36.

[34] Nusrat Sultana, Abdulla-Al-Asif, Md. Mehadi Imam Dihider, S.M. Ahsan, Faruki Shabia Maraj (2015), "Usefulness of Farm Women Training Programmes in Livelihood Security", International Journal of Business, Social and Scientific Research, 4: 13-24.

[35] Thomson K.T., Sk. Md. Dilbar Jahan and Md. Syed Hussain (1993), "Socioeconomic conditions of the Estuarine Set Bagnet Fisher folk in Bangladesh", (BOBP/WP/90).27pp.

[36] Suvashis Vaumik, Sourav Kumer Sarker, Md. Shahab Uddin, Md. Tariqul Alam, Abdus Satter, Abdulla-Al-Asif (2017), "Constraints and Prospects of Fish Farming in Lalmonirhat District", International Journal of Business, Social and Scientific Research, 5: 201-210.

[37] World Bank.1998. Bangladesh Fisheries Sectors Review Report No.8830-BD.

[38] Md. Farid Uz Zaman, Md. Abdus Samad, Md. Ariful Islam, Md. Hasan-Uj-Jaman, Shoumo Khondoker and Abdulla-Al-Asif (2017), "Assessment of sustainability of Pangasius (Pangasius hypophthalmus) farming at Jhikargachha upazila in Jessore district, Bangladesh", International Journal of Fauna and Biological Studies, 4: 109-119.

[39] Tanjeena Zaman, M.A.S. Jewel and A.S. Bhuiyan (2006), "Present status of pond fishery resources and livelihood of the fish farmers of MohanpurUpazila in Rajshahi District", University Journal of Zoology, Rajshahi University, 25: 31-35.

\footnotetext{
*Corresponding author.

E-mail address: atiqimsf@ gmail.com
} 